Gut, 1968, 9, 38-41

\title{
Effect of patterns of eating and antacids on faecal urobilinogen excretion
}

\author{
S. L. MALHOTRA ${ }^{1}$ \\ From the Medical Department, Western Railway, Bombay, India
}

It has been shown (Malhotra, 1968) that significantly higher amounts of faecal and urine urobilinogen are eliminated on the non-masticatory South Indian style diet as compared with the masticatory North Indian régime.

The present study was undertaken to separate the effect of the pattern of diet from the pattern of eating and also to study the effect of acid and antacids on these values.

\section{MATERIALS AND METHODS}

PATIENTS Twelve ambulatory, convalescent patients with complaints unrelated to the gastrointestinal tract and on no medication were included in the dietary experiments. All the studies were carried out in the metabolic ward of the Jagjivan Ram Hospital of the Western Railway.

THE DIETARY REgIMENS Two different diets were used, the masticatory wheat diet and the non-masticatory rice diet, which have been described elsewhere (Malhotra, 1968). These were isocaloric with each other at 2,271 calories.

In order to maintain uniformity in the composition of the diets, patients were served from a common pool of the respective diets. In the first set of experiments, which included six patients, the wheat diet was used first, followed by the rice diet; and in the second set, which had six patients, this sequence was changed, viz., the rice diet preceded the wheat diet. In each dietary régime, three different modes of ingestion were employed: (1) six days on the wheat or rice diet alone; (2) six days on the wheat or rice diet plus $100 \mathrm{ml}$. of $0.15 \mathrm{~N} \mathrm{HCl}$, three times daily after the principal meals; (3) six days on wheat or rice diet plus $100 \mathrm{ml}$. of $5 \%$ sodium bicarbonate and 2 teaspoonfuls of an antacid (Aludrox, M.H., John Weyth), three times daily, after the principal meals.

Lastly, a comparison was made between two different patterns of eating the rice diet, namely, by deliberate and thorough chewing versus 'meal scamping,' a pattern of eating which is habitual in South India and in which the patients bolt down handfuls of rice with minimal chewing.

'Present address and address for' reprints: Chief Medical Officer and Head of the Medical Department, South Eastern Railway, Garden Reach, Calcutta 43, India.
BIOCHEMICAL INVESTIGATIONS Methods of collecting stools and estimating faecal urobilinogen have been described in detail in another article in this Journal (Malhotra, 1968). We have observed in our pilot studies that with changes in dietary régimes, basal conditions in the levels of faecal and urine urobilinogen are not attained until two days after a particular dietary regimen, after which a high degree of repeatability of results is attained. We have, therefore, continued the different feeding schedules for a week but we have carried out the biochemical estimations only on the last three days' faecal collections of each schedule.

\section{RESULTS}

The result of the faecal urobilinogen concentration (mg. per $100 \mathrm{~g}$. of stool), the weight of faeces (g./24 hours), and the faecal urobilinogen excretion (mg./24 hours) are shown in Tables I, II, and III. In all 12 patients there was an increase in the faecal urobilinogen concentration when the feeding regimen was changed from the masticatory wheat diet to the sloppy rice diet; the mean values rose from $26.48 \mathrm{mg}$. to $86.98 \mathrm{mg}$. $/ 100 \mathrm{~g}$. of stool $(P<0.001)$. When antacids were given with the rice diet a fall in faecal urobilinogen concentration was noted in nine out of 12 patients, the respective mean values being $86.98 \mathrm{mg}$. compared with $62.46 \mathrm{mg} . / 100 \mathrm{~g}$. of stool. Similarly when rice was masticated well, in eight of 12 patients a fall in the urobilinogen concentration was noted, although there was no difference in the mean weight of the faeces (Table IV). As against this, no change in the mean faecal urobilinogen concentration occurred on the regimens combining either $\mathrm{HCl}$ or antacids with the masticatory wheat diet or of combining acid with the non-masticatory rice diet.

\section{DISCUSSION}

The rise in faecal urobilinogen concentration on the rice diet is significant when compared with the wheat diet $(P<0.001)$, and this agrees with our earlier results (Malhotra, 1968). When antacids are given with the non-masticatory rice diet, the 
TABLE I

MEAN FAECAL UROBILINOGEN CONCENTRATION WITH WHEAT DIET, WHEAT AND HCl, WHEAT AND ANTACIDS, RICE DIET, RICE AND HCl, AND RICE AND ALKALI

\begin{tabular}{|c|c|c|c|c|c|c|}
\hline Subject No. & $\underset{\text { (Wheat Diet) }}{A}$ & $\begin{array}{l}\text { B } \\
\text { (Wheat Diet } \\
\text { plus } 100 \mathrm{ml} \text {. } \\
0.15 \mathrm{~N} \mathrm{HCl} \text { ) }\end{array}$ & $\begin{array}{l}\text { C } \\
\text { (Wheat Diet } \\
\text { plus } 100 \mathrm{ml} \text {. } \\
5 \% \mathrm{Na} \mathrm{HCO} \text {. } \\
\text { and Aludrox) }\end{array}$ & $\begin{array}{l}D \\
\text { (Rice Diet) }\end{array}$ & $\begin{array}{l}\text { E } \\
\text { (Rice Diet plus } \\
100 \mathrm{ml} .0 \cdot 15 \mathrm{~N} \\
\mathrm{Hcl})\end{array}$ & $\begin{array}{l}\text { F } \\
\text { (Rice Diet plus } \\
100 \mathrm{ml} .5 \% \mathrm{Na} \\
\mathrm{HCO} \text { and Aludrox) }\end{array}$ \\
\hline $\begin{array}{r}1 \\
2 \\
3 \\
4 \\
5 \\
6 \\
7 \\
8 \\
9 \\
10 \\
11 \\
12\end{array}$ & $\begin{array}{r}53 \cdot 10 \\
12 \cdot 13 \\
27 \cdot 70 \\
10 \cdot 50 \\
38 \cdot 43 \\
14 \cdot 63 \\
44 \cdot 60 \\
26 \cdot 00 \\
8 \cdot 40 \\
37 \cdot 10 \\
16 \cdot 80 \\
28 \cdot 36\end{array}$ & $\begin{array}{l}47 \cdot 70 \\
14 \cdot 30 \\
34 \cdot 20 \\
12 \cdot 36 \\
35 \cdot 60 \\
23 \cdot 30 \\
46 \cdot 30 \\
34 \cdot 50 \\
10 \cdot 20 \\
37 \cdot 90 \\
19 \cdot 20 \\
25 \cdot 20\end{array}$ & $\begin{array}{l}37 \cdot 50 \\
12 \cdot 30 \\
29 \cdot 90 \\
19 \cdot 90 \\
27 \cdot 07 \\
28 \cdot 10 \\
31 \cdot 10 \\
30 \cdot 30 \\
26 \cdot 10 \\
32 \cdot 70 \\
20 \cdot 30 \\
21 \cdot 30\end{array}$ & $\begin{array}{r}85.5 \\
68.3 \\
117.8 \\
67.6 \\
82.7 \\
57 \cdot 7 \\
117.4 \\
118.4 \\
95 \cdot 8 \\
107.6 \\
63.3 \\
61.7\end{array}$ & $\begin{array}{r}73 \cdot 8 \\
106 \cdot 1 \\
71 \cdot 5 \\
66 \cdot 3 \\
62 \cdot 2 \\
32 \cdot 0 \\
94 \cdot 4 \\
109 \cdot 0 \\
62 \cdot 3 \\
105 \cdot 5 \\
60 \cdot 1 \\
60.7\end{array}$ & $\begin{array}{r}76 \cdot 4 \\
81 \cdot 5 \\
117 \cdot 4 \\
49 \cdot 3 \\
88 \cdot 4 \\
48 \cdot 9 \\
47 \cdot 2 \\
76 \cdot 4 \\
44 \cdot 3 \\
57 \cdot 4 \\
27 \cdot 0 \\
35 \cdot 4\end{array}$ \\
\hline Total & $317 \cdot 75$ & 340.76 & 316.57 & $1,043 \cdot 8$ & 903.9 & $749 \cdot 6$ \\
\hline S.E. & $4 \cdot 28$ & $3 \cdot 70$ & 1.98 & 6.84 & $6 \cdot 76$ & $7 \cdot 48$ \\
\hline S.E. of mea & $\begin{array}{l}\text { rence: } A \text { vs I } \\
\text { A vs I } \\
\text { D vs }\end{array}$ & $\begin{array}{l}1 \cdot 2110, \mathrm{t}=1 \cdot \\
7 \cdot 3121, \mathrm{t}=8 \cdot 2 \\
7 \cdot 4800, \mathrm{t}=3 \cdot 2\end{array}$ & $\begin{array}{l}\text { vs } C \pm 3.0722 \text {, } \\
\text { vs } E \pm 6.2315 \text {, }\end{array}$ & $\begin{array}{l}0.03 \\
1 \cdot 87\end{array}$ & & \\
\hline
\end{tabular}

TABLE II

MEAN WEIGHI OF FAECES EXCRETED WITH WHEAT DIET, WHEAT AND HCl, WHEAT AND ANTACIDS, RICE DIET, RICE AND HCl, AND RICE AND ALKALI

\begin{tabular}{|c|c|c|c|c|c|c|}
\hline Subject No. & $\underset{\text { (Wheat Diet) }}{A}$ & $\begin{array}{l}\text { B } \\
\text { (Wheat Diet } \\
\text { plus } 100 \mathrm{ml} \text {. } \\
0.15 N \mathrm{HCl} \text { ) }\end{array}$ & $\begin{array}{l}\text { C } \\
\text { (Wheat Diet } \\
\text { plus } 100 \mathrm{ml} . \\
5 \% \text { Na HCO, } \\
\text { and Aludrox) }\end{array}$ & $\begin{array}{l}\text { D } \\
\text { (Rice Diet) }\end{array}$ & $\begin{array}{l}E \\
\text { (Rice Diet plus } \\
100 \mathrm{ml} .0 \cdot 15 \mathrm{~N} \\
\mathrm{HCl})\end{array}$ & $\begin{array}{l}\text { F } \\
\text { (Rice Diet plus } \\
100 \mathrm{ml} .5 \% \mathrm{Na} \\
\mathrm{HCO} \text { and Aludrox) }\end{array}$ \\
\hline $\begin{array}{r}1 \\
2 \\
3 \\
4 \\
5 \\
6 \\
7 \\
8 \\
9 \\
10 \\
11 \\
12\end{array}$ & $\begin{array}{l}220 \\
225 \\
325 \\
164 \\
153 \\
214 \\
253 \\
391 \\
188 \\
231 \\
216 \\
203\end{array}$ & $\begin{array}{r}235 \\
283 \\
212 \\
183 \\
147 \\
190 \\
328 \\
278 \\
182 \\
120 \\
80 \\
203\end{array}$ & $\begin{array}{l}210 \\
232 \\
193 \\
207 \\
196 \\
184 \\
226 \\
303 \\
194 \\
183 \\
304 \\
294\end{array}$ & $\begin{array}{r}192 \\
140 \\
163 \\
71 \\
54 \\
132 \\
144 \\
184 \\
88 \\
54 \\
265 \\
135\end{array}$ & $\begin{array}{r}169 \\
205 \\
279 \\
141 \\
73 \\
209 \\
152 \\
162 \\
89 \\
86 \\
138 \\
140\end{array}$ & $\begin{array}{r}172 \\
102 \\
133 \\
22 \\
65 \\
170 \\
204 \\
192 \\
263 \\
174 \\
220 \\
174\end{array}$ \\
\hline Total & 2,783 & 2,441 & 2,726 & 1,622 & 1,843 & 1,891 \\
\hline Mean & 232 & 203 & 227 & $135 \cdot 1$ & 153.5 & $157 \cdot 5$ \\
\hline S.E. & $19 \cdot 27$ & $20 \cdot 42$ & 13.47 & 18.04 & 16.89 & 19.46 \\
\hline S.E. of mear & 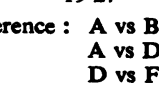 & $\begin{array}{l}0.7745, \mathrm{t}-1 \\
9.5202, \mathrm{t}=4 \\
0.0462, \mathrm{t}-1\end{array}$ & $\begin{array}{l}\text { s } C \pm 19 \cdot 237 \\
\text { is } E \pm 18.0809\end{array}$ & $\begin{array}{l}-0.24 \\
1.01\end{array}$ & & \\
\hline
\end{tabular}

concentration of urobilinogen falls significantly $(P<0.01)$. But this does not happen when antacids are given with the masticatory diet $(t=0.03)$. The effect of deliberate chewing of the sloppy rice diet is a significant fall in the urobilinogen concentration, as compared with 'meal scamping' $(P<0.01)$.

The data in Tables II and III indicate that the changes in faecal urobilinogen concentration are due to an absolute increase in the total amount of faecal urobilinogen (mg./24 hours) and not merely to dilution. Since urobilinogen is formed in the intestine by the reduction of bilirubin, and its amount in faeces depends primarily on the amount of bilirubin entering the intestine (Varley, 1962), the findings recorded here suggest that important differences in the amounts of bilirubin entering the intestinal lumen take place not only as a result of differences in the pattern of diet but also in the pattern of eating.

While the actual mechanism of these differences is less clear, these may be explained by the effect of diet and antacids on gall-bladder evacuation reported elsewhere (Malhotra, 1967, 1967a, 1968). Magee $(1962,1965)$ has shown in his experimental 
TABLE III

MEAN FAECAL UROBILINOGEN EXCRETION WITH WHEAT DIET, WHEAT AND HCl, WHEAT AND ANTACIDS, RICE DIET, RICE AND HCl, AND RICE AND ANTACIDS

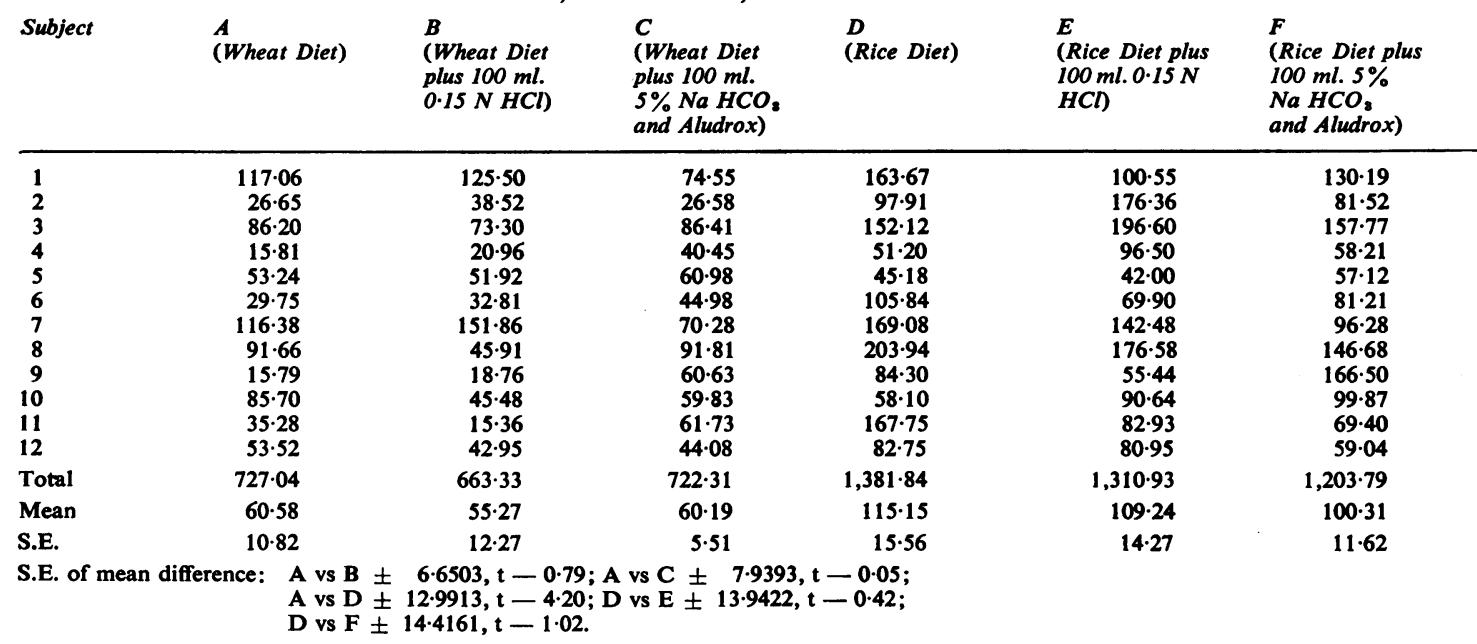

studies that hydrochloric acid is by far the most potent duodenal stimulus for gall-bladder contraction; $p \mathrm{H}$ alone is not responsible for the mechanism as $\mathrm{N} / 10$ acetic acid did not contract the gall-bladder. The fact that painting the duodenal mucosa with $2 \%$ procaine abolished the stimulatory effect of $\mathrm{HCl}$ on gall-bladder contraction (Hong, Magee, and Crewdson, 1956) has been interpreted to mean that the local action of the anaesthetic had prevented the stimuli responsible for cholecystokinin release reaching the receptors (Magee, 1965). The fall in faecal urobilinogen when antacids were administered with the sloppy rice diet might be explained by the reduction in the intensity of the $\mathrm{HCl}$ as a stimulus brought about by its neutralization with antacids. A similar fall did not occur when antacids were given with the masticatory wheat diet and this may be explained by the fact that the chewing movements of the jaw produce saliva of a higher buffer capacity and in larger total volume (Wills and Forbes, 1939; Sand, 1951; Weschler, 1959; Malhotra, Saigal, and Mody, 1965) which has a better competence to neutralize $\mathrm{HCl}$ (Malhotra, 1967b), thus resulting in a decrease in its stimulus intensity due to the pattern of eating itself, with the result that antacids did not produce any further fall.

Since the faecal urobilinogen concentration significantly fell when the sloppy rice diet was deliberately macerated and chewed (Table IV) it is clear that some changes had taken place in the diet during mastication which exert a regulatory influence on the contraction of the gall-bladder. The nature of these changes is not entirely clear but may have been brought about by the added saliva,
TABLE IV

COMPARISON BETWEEN RICE DIET EATEN BY THOROUGH CHEWING VERSUS RICE DIET EATEN HABITUALLY IN 12 ADULT HEALTHY MALES

\begin{tabular}{|c|c|c|c|c|}
\hline \multirow[t]{2}{*}{ Subject } & \multicolumn{2}{|c|}{$\begin{array}{l}\text { Mean Faecal Urobilinogen } \\
\text { Concentration (mg. per } \\
100 \text { g. stools) }\end{array}$} & \multicolumn{2}{|c|}{$\begin{array}{l}\text { Mean Weight of Faeces } \\
(\mathrm{g} . / 24 \text { hours })\end{array}$} \\
\hline & $A$ & $\boldsymbol{B}$ & $A$ & $\boldsymbol{B}$ \\
\hline $\begin{array}{r}1 \\
2 \\
3 \\
4 \\
5 \\
6 \\
7 \\
8 \\
9 \\
10 \\
11 \\
12\end{array}$ & $\begin{array}{r}85 \cdot 5 \\
68 \cdot 3 \\
117 \cdot 8 \\
67 \cdot 6 \\
82 \cdot 7 \\
57 \cdot 7 \\
117 \cdot 4 \\
118 \cdot 4 \\
95 \cdot 8 \\
107 \cdot 6 \\
63 \cdot 3 \\
61 \cdot 7\end{array}$ & $\begin{array}{r}84 \cdot 1 \\
80 \cdot 3 \\
79 \cdot 2 \\
37 \cdot 6 \\
113 \cdot 0 \\
37 \cdot 3 \\
65 \cdot 0 \\
64 \cdot 0 \\
24 \cdot 4 \\
113 \cdot 0 \\
38 \cdot 7 \\
23 \cdot 95\end{array}$ & $\begin{array}{r}163.67 \\
97.91 \\
152 \cdot 12 \\
51.20 \\
45 \cdot 18 \\
105 \cdot 84 \\
169.08 \\
203.94 \\
84.30 \\
58 \cdot 10 \\
167 \cdot 75 \\
82.75\end{array}$ & $\begin{array}{r}165.66 \\
98.75 \\
175.67 \\
68.08 \\
29 \cdot 19 \\
79 \cdot 10 \\
165.00 \\
140 \cdot 16 \\
25.62 \\
109.61 \\
102.16 \\
80.14\end{array}$ \\
\hline Total & $1,043 \cdot 8$ & 760.55 & $1,381 \cdot 84$ & $1,239 \cdot 14$ \\
\hline Mean & 86.98 & $63 \cdot 38$ & $115 \cdot 15$ & $103 \cdot 26$ \\
\hline \multirow{2}{*}{ S.E. } & 6.84 & $9 \cdot 10$ & $14 \cdot 27$ & 14.66 \\
\hline & \multicolumn{2}{|c|}{$\begin{array}{l}P<0.01 \\
A=\text { no chewing }\end{array}$} & \multicolumn{2}{|c|}{$\begin{array}{l}\mathbf{P}-\text { Not significant } \\
\mathbf{B}=\text { chewing }\end{array}$} \\
\hline
\end{tabular}

as the chewing movements of the jaw produce saliva of a higher buffer capacity and in larger total volume (Wills and Forbes 1939; Sand, 1951; Malhotra, 1965; Malhotra et al., 1965). Since masticatory meals can better reduce gastric acidity (Malhotra et al., 1965; Malhotra, 1967b), this may mean that the masticatory mode of eating had brought about a decrease in the stimulus-intensity of $\mathrm{HCl}$ for gall-bladder contraction. Another possible explanation for this might be that the mucus of the added saliva is precipitated on coming in contact with gastric $\mathrm{HCl}$, and in this state is less 
permeable to the stimuli responsible for release of cholecystokinin, which may thus be prevented from reaching the receptors. There is evidence that chewing movements of the jaw increase the mucus content of saliva (Dewar and Parfitt, 1954; Malhotra et al., 1965; Malhotra, 1967c), with the result that the concentration of mucus in the gastric juice is greater in the case of masticatory as compared with non-masticatory food (Malhotra, 1967c). This explains why giving acid with a masticatory diet did not produce a rise in faecal urobilinogen excretion. It is also probable that the physical state of the ingested food itself, which in the case of sloppy meals might form a coarse and a more permeable layer, and in the case of the well-masticated food the finely divided food matter resting on the mucosa forms a less permeable layer. We have no evidence on which to base a distinction between these two possible mechanisms of the influence of the pattern of eating on gall-bladder contraction, and both may be concerned. It is noteworthy that in ruminants, which chew their food well, one generally finds a full gall-bladder at slaughter, whether the animals are fed or fasted (Magee, 1965), and this might be due to a similar mechanism.

\section{SUMMARY}

Faecal urobilinogen concentration (mg./100 g. stool) and excretion (mg./24 hours) rise when patients on a masticatory wheat diet are changed to a non-masticatory rice diet. These values are influenced also by the ingestions of hydrochloric acid as well as antacids. While antacids produce a fall in these values in the case of a non-masticatory diet, they have no effect in the case of the masticatory diet. On the other hand giving of acid produced no change either with the masticatory or with the non-masticatory diet. Deliberate chewing of the non-masticatory diet results in a significant fall in faecal urobilinogen excretion, indicating that the addition of saliva to the food during mastication is responsible for this difference, and it may act by virtue of its acid-neutralizing properties since hydrochloric acid is the most potent duodenal stimulus for gall-bladder evacuation, or by virtue of its mucus content which may prevent stimuli responsible for the release of cholecystokinin reaching the receptors.

\section{REFERENCES}

Dewar, M. R., and Parfitt, G. J. (1954). An investigation of the physical properties of saliva and their relationship to the mucin content. J. dent. Res., 33, 596-605.

Hong, S. S., Magee, D. F., and Crewdson, F. (1956). The physiologic regulation of gall bladder evacuation. Gastoenterology, 30, 625-630.

Magee, D. F. (1962). Gastro-intestinal Physiology, p. 68. Thomas, Springfield, III.

- (1965). The physiology of gall-bladder emptying. In Symposium of the NATO Advanced Study Institute on the Biliary System, p. 235. Blackwell, Oxford.

Malhotra, S. L. (1965). Peptic ulcer: role of saliva in its aetiology. J. Ass. Phycns India, 13, 907-914.

- (1967). Effect of diet and antacids on gall-bladder emptying. Abstr. Proc. 3rd Wld Congr. Gastroenterology, Tokyo, Japan, 1966, 2-106.

- (1967a). Effect of antacids on gall-bladder evacuation. Abstr. Proc. 3rd Wld Congr. Gastroenterology, Tokyo, Japan, 1960, 2-106.

- (1967b). Protective action of saliva in peptic ulceration. A study of its effect on gastric juice by dye dilution technique. Under publication in Scand. J. Gastroent, 2, 95 Abstr. Proc. 3rd Wld Congr. Gastroenterology, Tokyo, Japan, 1966, 1-44.

- (1967c). A study of the effect of saliva on the concentration of mucin in the gastric juice and its possible relationship to the aetiology of peptic ulcer. Gut. 8, 548-555.

(1968). Effect of diet on faecal and urine urobilinogen excretion and its possible relationship to the pathogenesis of peptic ulceration. Gut, 9, 38-41.

Saigal, O. N., and Mody, G. D. (1965). Role of saliva in the aetiology of peptic ulcer. Brit. med. J., 1, 1220-1222.

Sand, H. F. (1951). Source of the bicarbonate of saliva. J. appl. Physiol., 4, 66-76.

Varley, H. (1962). Practical Clinical Biochemistry, 3rd, ed. p. 296. Heinemann, London.

Weschler, A. (1959). The secretion of bicarbonate in saliva. M.Sc. Thesis. McGill University. Quoted in Burgen A. S., and Emmelin, N. G. (1961). Physiology of the Salivary Glands, pp. 145-147. Arnold, London.

Wills, J. H., and Forbes, J. C. (1939). Dietary effects upon the acid neutralising power of the saliva. J. dent. Res., 18, 409-415. 